岡山医誌（1990）102，899 909

\title{
アレルギー性肺疾患における 末梢気道領域の免疫応答に関する研究
}

\author{
第 1 編 \\ 間質性肺疾患における末梢気道肺胞領域の免疫組織学的検討 \\ 岡山大学医学部第二内科学教室（指導：木村郁郎教授） \\ 尾崎公孝
}

(平成 2 年 5 月 10 日受稿)

\begin{abstract}
Key words : small airway, immunohistopathology, normal lung, interstitial pneumonia, sarcoidosis
\end{abstract}

\section{緒言}

健常人における気道の㴼性免疫防御機構の主 体は, 通常, 分緒型 $\operatorname{IgA}$ として気道粘膜表面に 多量に存在する IgA 抗体であり ${ }^{122)}$, さらに，呼 吸器疾患における気管支粘膜局所においても， 免疫グロブリン (Ig) 産生細胞の多くは IgA 産 生細胞であり，他のクラスは低率である゙．しか し，各種の炎症反応を繰り返すことにより，生 体防御機構の一環として, 体液性・細胞性免疫 ネットワークが強化されてくる。かかる防御機 構の成立には，外的内的な多くの要因の違いに よって，それぞれ異なった機序が想定され，例 えば、型アレルギー反応に基すく気管支喘息で は, IgE 抗体の局所産生が報告されており 、ま た、慢性気道感染症では IgG 抗体の関与が想定 されるなど，疾患病態によって免疫ネットワー クの稳度が異なる。さらに，末梢気道領域に病 変の主座を有する各種の間質性呼吸器突患で, その病因に様々な免疫学的異常が想定されてい る。例之ば，特発性間質性肺炎 (IIP) における immune complex の関与5)や，過敏性肺蔵炎に おける川型およU゙V型アレルギーの関与6)など, 複雑な免疫アレルキ゚ーの翼常が考之られている。 また, 従来I型アレルギー反応によると考えられ ていた気管支喘息においても, 近年, 特に非つ トピー型喘息や重症の難治性喘息においては,
IgG 系の反応が注目されている78)。また難治性 喘息においては，末梢気道領域に器質的変化を 伴う症例が多〈910), 末梢気道における免疫反応 が注目される。

この上うな，各種の免疫学的呼吸器疾患の末 梢気道領域における病態を解明する一助として, 本編では, まず健常肺の末梢領域の免疫組織学 的特徵を明らかにする目的で, 健常肺の細気管 支肺胞領域において, 各 $\operatorname{Ig}$ 産生細胞の局在及び, $\mathrm{Ig}$ や免疫複合体の間質への分布を観察し，さら に, 免疫学的異常を伴うと考えられる, 各種呼 吸器疾患の生検肺において, 同様の観察を行い, 健常肺のそれと比較検剑した。

\section{对象ならびに方法}

対象：健常肺としては，8症例（全例男性, 35-71歳, 平均58.3歳) の肺癌患者で手術切除 肺の健常末梢部分を用いた。各種間質性肺疾患 としては，間質性肺炎（IP）４例 [特発性間質 性肺炎(IIP) 2 例，リウマ千肺 2例]，過敏性肺 眼炎（HP） 3 例，サルコイドーシス (サ症) 3 例，びまん性沉細気管支炎（DPB）3例の計13 例を对象に，経気管支肺生検法 (transbronchial lung biopsy，TBLB）にて，末梢肺生検を実施 した。各症例の性別，年齢は Table 1 に示す。 なお, positive control として, ヒ卜甬桃の切片 標本を, negative control として, 一次抗体の 
Table 1 Clinical and histological findings

\begin{tabular}{|c|c|c|c|c|c|}
\hline $\begin{array}{c}\text { Case } \\
\text { no }\end{array}$ & Age & Sex & Nature of Specimen & Histological Diagnosis & Clinical Diagnosis \\
\hline \multicolumn{6}{|c|}{ Normal lungs } \\
\hline 1 & 70 & M & Lobectomy & Normal & Lung cancer \\
\hline 2 & 53 & M & Lobectomy (RLL) & Normal & Lung cancer \\
\hline 3 & 71 & M & Partial resection & Normal & Lung cancer \\
\hline 4 & 55 & M & Lobectomy & Normal & Lung cancer \\
\hline 5 & 65 & $\mathrm{M}$ & Lobectomy (RUL) & Normal & Lung cancer \\
\hline 6 & 35 & M & Lobectomy (RLL) & Normal & Lung cancer \\
\hline 7 & 59 & $\mathrm{M}$ & Lobectomy (RUL) & Normal & Lung cancer \\
\hline 8 & 58 & M & Lobectomy & Normal & Lung cancer \\
\hline \multicolumn{6}{|c|}{ Diseased lungs } \\
\hline 9 & 57 & F & TBLB & UIP & I.I.P. \\
\hline 10 & 43 & M & Open lung biopsy & UIP & I.I.P. \\
\hline 11 & 50 & $\mathrm{M}$ & TBLB & Interstitial preumonia & I.P. with R.A. \\
\hline 12 & 55 & $\mathrm{~F}$ & TBLB & Interstitial preumonia & I.P.with R.A. \\
\hline 13 & 39 & $\mathrm{~F}$ & TBLB & Granulomatous alveolitis & H.P. \\
\hline 14 & 61 & $F$ & TBLB & Granulomatous alveolitis & H.P. \\
\hline 15 & 42 & $F$ & TBLB & Granulomatous alveolitis & H.P. \\
\hline 16 & 34 & $\mathrm{M}$ & TBLB & Sarcoidosis & Sarcoidosis \\
\hline 17 & 59 & $\mathrm{M}$ & TBLB & Sarcoidosis & Sarcoidosis \\
\hline 18 & 52 & $F$ & TBLB & Sarcoidosis & Sarcoidosis \\
\hline 19 & 46 & M & Open lung biopsy & Bronchiolitis & DPB \\
\hline 20 & 54 & $\mathrm{~F}$ & TBLB & Bronchiolitis & $\mathrm{DPB}$ \\
\hline 21 & 61 & $\mathrm{~F}$ & TBLB & Bronchiolitis & DPB \\
\hline
\end{tabular}

みを省いたヒト肺の切片標本を使用した。

方法：1) 検体の採取：健常肺は, 肺癌切除 肺のうち肉眼的ならびに、レ線学的に翼常を認 めない末梢肺組織を, $1 \mathrm{~cm} \times 1 \mathrm{~cm} \times 1 \mathrm{~cm}$ の大 さに切り出し, 速やかに $10 \%$ ホルマリン固定し た。各種呼吸器疾患では，気管支ファイバース コープ（オリンパス $1 \mathrm{~T}-10)$ を経気道的に挿入 し, 右下莱の $\mathrm{S}_{8}, \mathrm{~S}_{9}$ 上り TBLB 法にて, 細気 管支肺胞領域の組織を， 3-4 個ずつ採取し． 陰圧にて拡張した後，10\%ホルマリン液で24時 間固定した。

2) 免疫染色法：ホルマリン固定した検体を パラフィン包埋し、ミクロトームにて，4-6 $\mu \mathrm{m} に$ て薄切して, スライドダラスに榔布し, 充 分に乾燥させた。免疫染色法の概略は，Fig. 1 に示すように, peroxidase antiperoxidase methodに従った。すなわち, 脱パラフィンは,
(1) Deparaffinization.

(2) Endogenous peroxidase blocking.

(3) Trypsinization.

(4) Incubation with $10 \%$ normal swine serum.

(5) Incubation with primary antiserum (antihuman rabbit serum) for $30 \mathrm{~min}$. at room temperature.

(5) Incubation with secondary antiserum (antirabbit swine serum) for $30 \mathrm{~min}$. at room temperature.

(7) Incubation with peroxidase-antiperoxidase soluble complex for $30 \mathrm{~min}$. at room temperature.

(8) Incubation with $0.02 \%$ diaminobenzidine for $2 \mathrm{~min}$. at room temperature.

(9) Staining of nucleus with hematoxylin.

Fig. 1 Peroxidase antiperoxidase procedure, 
キシレンに 5 分間, 3 回の計15分間浸透させて 行い，その後100\%エタノールに1分間，3回浸 透した後，流水にて洗净した。赤血球，好酸球， 好中球，単球，マクロファージに存在する内因 性ペルオキシターゼ活性を阻止するために, 0.3 \%過酸化水素加メタノールに30分間浸透した。 ホルマリン固定は，蛋白質抗原の cross linkage によるが, 間質に沈着したIgや補体の抗原性を maskingする危険があるため, 0.1\%塩化カルシ ウム加0.1\%卜リプシン水溶液にて、37 $37^{\circ} \mathrm{C} て ゙ 30$ 分 incubate した。その後, pH7.6の TBS (tris buffer 液）にて，5分間 2 回洗浄した後，nonspecific back ground staining を防ぐために, 10\%正常ブ夕血清を切片にかけて, 10分間 incubate した。その後，標的抗原に对要る特異的抗 体として，DAKO 社製家鬼血清，抗七卜 IgG， IgA, IgM, IgE 及び, 抗ヒト $\mathrm{C}_{1} \mathrm{q}$ をマイクロ ピペットにて各切片上にかけ, moist chamber にて室温で30分反応させた。なお，予め検討し た抗体の至適濃度は，抗 IgG，IgA，IgM 抗体 が, $1 / 1000$, 抗 $\operatorname{IgE}$ 抗体が $1 / 100$, 抗 $\mathrm{C}_{1} \mathrm{q}$ 抗体 が1/200の各希䣋倍率であった。TBSで5分間 3 回水洗した後、二次抗体である抗家兔ブタ血 清をTBSにて1/100に希釈して，各切片に滴下 し， moist chamberにて30分 incubate した。 再じ，TBS で 5 分間 3 回水洗の後，1/100に希 釈した peroxidase antiperoxidase complex (DAKO 社製)を滴下して, moist chamber で, 30分間反応させた。水洗の後, DAB液( 3,4 , 3', 4 'tetraaminobiphenyl hydrochloride 30 $\mathrm{mg} 150 \mathrm{ml} の \mathrm{TBS}$ に溶解し， $30 \%$ 過酸化水素水 を添加したもの)に 2 分間浸透して発色させた。 最後にへマトキシリンにて核染色した。

3）評価法：上述の方法に上り細気管支肺胞 領域に存在する IgG，IgA，IgE及び $\mathrm{C}_{1} \mathrm{q}$ を免 疫染色し, $\times 400$ 光顕下にて全視野を観察し，以 下の項目について評価した。

a) 各 Ig 含有細胞の分布：標本切片上，細気 管支肺胞領域に局在する Ig 含有細胞を各 Ig ク ラス別に全視野算定し， IgG， IgA， IgM, IgE の百分率比で示した。

b) 各 $\mathrm{Ig}$ 及U゙ $\mathrm{C}_{1} \mathrm{q}$ の間質への沈着：胞隔， 脈管内, 肺胞埶内, 肺胞マクロファージ内, 細
気管支粘膜内に区分し，各部位での免疫染色の 強さで,

㓌性 $(-)$ : negative control と同程度

弱陽性 $( \pm):$ ） 一の中間

陽性 $(+)$ ：形質細胞より弱いが明かな陽性

強陽性 $(2+)$ : 形質細胞と同程度

に分類して評洒した。なお，形質細胞は同一切 片上に見られるものを基準とした。

\section{成績}

\section{1. 健常人}

1) 含有細胞の分布 (Table 2)：Ig 含有細胞 は，肺末梢領域にも広く分布しており，特に細 気管支領域に多数見られた。case 6では，終末 細気管支粘膜下に BALT 様の単核球の集族を 認め，その中には IgA 及び IgG 含有細胞を少 数認めた。肺胞領域では, Ig 含有細胞は少なく， 所々に散見された。陽性細胞の多くは，大型の 楕円形の細胞で，扁在性の類円形の核と，豊富 な細胞質を持ち，細胞質が濃い褐色に染まって おり，成熟した形質細胞と思われた(Photo 1$) 。$

Table 2 Ig containing cell counts of eight normal lungs

\begin{tabular}{|c|c|c|c|c|c|c|c|}
\hline \multirow{2}{*}{ Case no } & \multirow{2}{*}{$\begin{array}{c}\text { Size of } \\
\text { specimen } \\
\left(\mathbf{m i z}^{2}\right)\end{array}$} & \multirow{2}{*}{ Site } & \multicolumn{5}{|c|}{ Ig containing cell counts } \\
\hline & & & IgG & $\operatorname{IgA}$ & $\operatorname{lgM}$ & IgE & Tota! \\
\hline \multirow{3}{*}{1} & \multirow{3}{*}{104} & Al & 34 & 80 & 8 & 0 & 122 \\
\hline & & $\mathbf{B r l}$ & 32 & 98 & 1.3 & 0 & 143 \\
\hline & & Total & 66 & 178 & 21 & 0 & 265 \\
\hline \multirow{3}{*}{2} & \multirow{3}{*}{123} & Al & 22 & 52 & 27 & 1 & 102 \\
\hline & & $\mathrm{Brl}$ & 31 & 84 & 22 & 0 & 137 \\
\hline & & Total & 53 & 136 & 49 & 1 & 239 \\
\hline \multirow{3}{*}{3} & \multirow{3}{*}{97} & Al & 5 & 6 & 0 & 0 & 11 \\
\hline & & $\mathrm{Brl}$ & $\mathbf{0}$ & 3 & 0 & 0 & 3 \\
\hline & & Total & $\mathbf{5}$ & 9 & 0 & 0 & 14 \\
\hline \multirow{3}{*}{4} & \multirow{3}{*}{30} & $\mathrm{Al}$ & 4 & 12 & 0 & 0 & 16 \\
\hline & & $\mathrm{Brl}$ & 9 & 93 & 11 & 0 & 113 \\
\hline & & Total & 13 & 105 & 11 & 0 & 129 \\
\hline \multirow{3}{*}{5} & \multirow{3}{*}{42} & $\mathrm{Al}$ & 0 & 18 & 4 & 2 & 24 \\
\hline & & $\mathrm{Brl}$ & 0 & 23 & 3 & 2 & 28 \\
\hline & & Total & 0 & 41 & 7 & 4 & 52 \\
\hline \multirow{3}{*}{6} & \multirow{3}{*}{60} & $\mathrm{Al}$ & 39 & 48 & 12 & 0 & 99 \\
\hline & & $\mathrm{Brl}$ & 48 & 103 & 21 & 0 & 172 \\
\hline & & Total & 87 & 151 & 33 & 0 & 271 \\
\hline \multirow{3}{*}{7} & \multirow{3}{*}{47} & $\mathrm{Al}$ & 2 & 51 & 3 & 1 & 11 \\
\hline & & $\mathrm{Brl}$ & 3 & 21 & 9 & 1 & 34 \\
\hline & & Total & 5 & 26 & 12 & 2 & 45 \\
\hline \multirow{3}{*}{8} & \multirow{3}{*}{72} & Al & 13 & 38 & 9 & 0 & 60 \\
\hline & & $\mathrm{Brl}$ & 51 & 104 & 46 & 0 & 201 \\
\hline & & Total & 64 & 142 & 55 & 0 & 261 \\
\hline
\end{tabular}




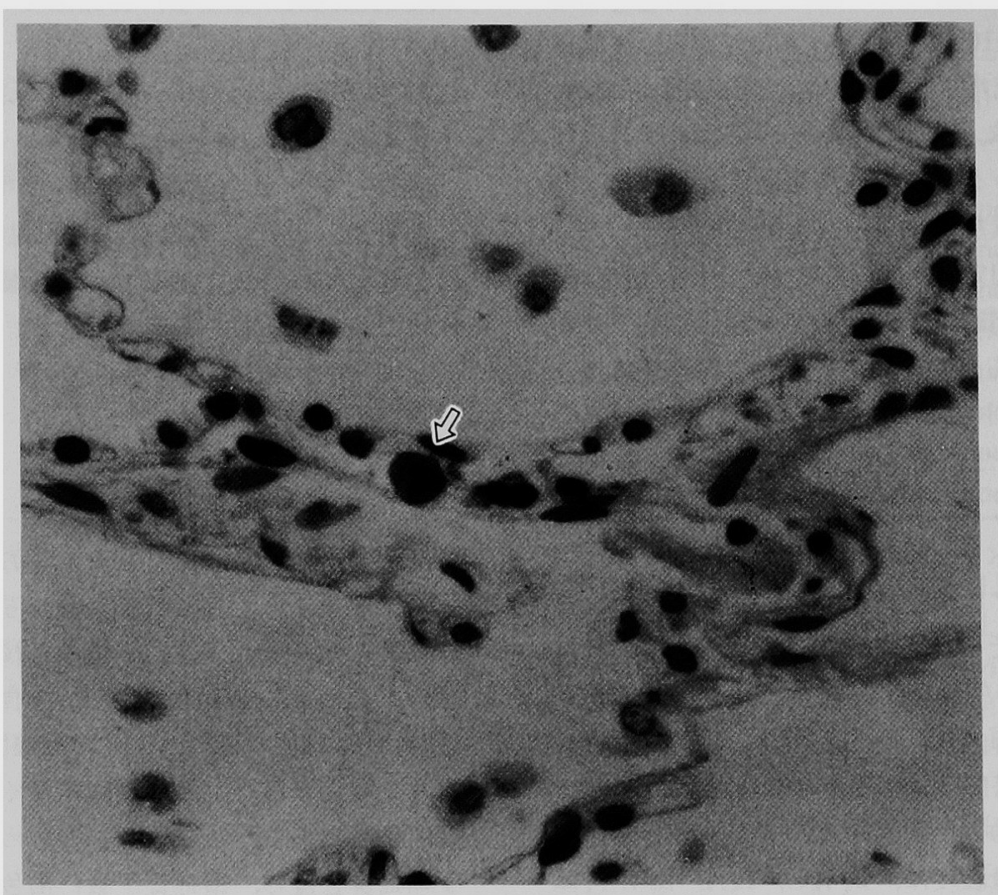

Photo $1 \operatorname{IgA}$ containing cell seen in the alveolar septum of normal lung $(\times 400)$

他に少数の、細胞質にそしい細胞が散見された が，恐らく Bリンハ球であろうと思われた。Ig クラス別で見ると， IgA 陽性細胞が，8例全例 で最も高率であり，その比率は，54.4\% (case 8) から $81.4 \%$ (case 4 ) で, 平均 $64.6 \%$ であ つた。次に IgG 陽性細胞の比率が高く, 平均20.1 \%を占めていたが, case 5 と case 7 では IgG 陽性細胞よりも, IgM 陽性細胞の方が多くみら れ, IgG と IgM との間に推計学的有意差は, 認められなかった。IgM陽性細胞の比率は, 平 均 $13.7 \%$ と, IgGに次いで多い傾向であった。 IgE 陽性細胞は，8例中 5 例で全く見られず, 他の症例もいずれもごく少数で, 平均1.6\%であ った (Fig. 2)。

2) $\operatorname{Ig}$ 及び $C_{1} q$ の間質への沈着 (Table 3 ): 胞隔には, case 1 で IgG, IgA, $\mathrm{C}_{1} \mathrm{q}$ が弱陽性, case $2 ， 3$ で $\mathrm{C}_{1} \mathrm{q}$ が弱陽性であったが，染色濃 度はきわめて弱く, nonspecific staining と考之 られた。他の症例では，各 Ig， C、q はいずれも 陰性であった。血管腔内は, case 6 で IgG, IgA, IgM が陽性であったが，他の症例では，いずれ

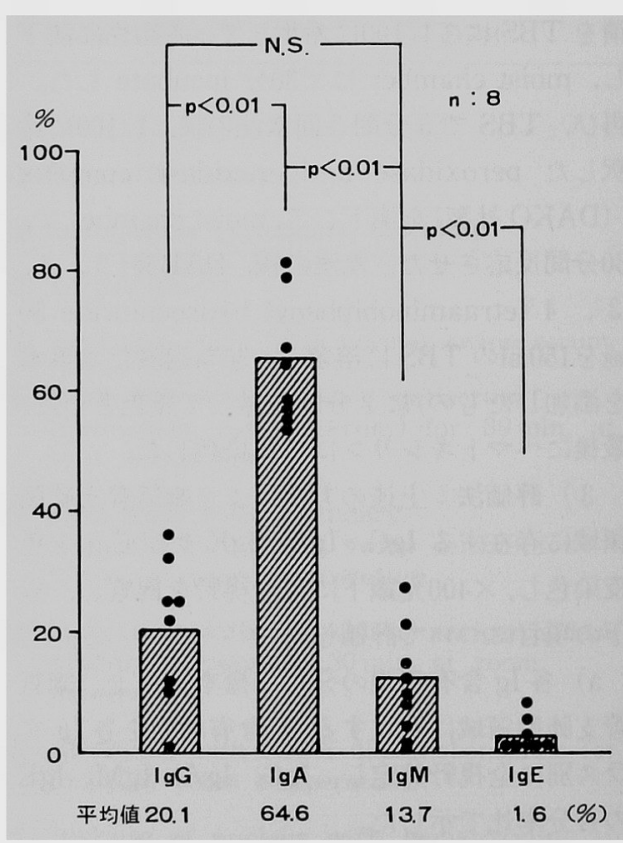

Fig. 2 Ratio of each Ig containing cell counts in 8 normal lungs 
の抗原も陰性だった。肺胞腔内には，いずれの $\mathrm{Ig}, \mathrm{C}_{1} \mathrm{q}$ も認められなかった。肺胞マクロファー ジ内には，IgG，IgA， $\mathrm{C}_{1} \mathrm{q}$ が時に弱陽性ながら 認められた。細気管支粘膜下には,いずれの Ig, $\mathrm{C}_{1} \mathrm{q}$ とも沈着していなかった。従って，血管内 腔や肺胞マクロ.ファージ内には，時に $\mathrm{Ig} や \mathrm{C}_{1} \mathrm{q}$ が認められたが，細気管支から肺胞に至る末梢 肺の間質には，認められなかった。

2. 各種肺疾患 (Table 4, Fig 3,4)

1）間質性肺炎（case 9-12）：これらの症例 の細気管支肺胞領域には, IgG, IgA 陽性細胞を 中心に, 多数の Ig 陽性細胞が認められた。IP
では, 胞隔は著明に線維性肥厚をきたしており， そこに多数のリンバ球や好酸球の浸潤を認める が, Ig 陽性細胞も，かかる浸潤細胞の多い胞隔 を中心に分布していた。なお，4例中 2 例 (case11, 12)のりウマチ肺の症例では, IgG 抗 体の胞隔への沈着が高度であったため, IgG 陽 性細胞の識別が不可能であったが, 他の 2 例 (case $9,10) の I I P$ 症例では，IgG 陽性細胞の比率は， $43.9 \%, 43.6 \%$ と健常肺の $20.1 \%$ に比して，2 倍以上の高值であった。一方，IgA 陽性細胞は $43.2 \%, 49.0 \%$ と健常肺における IgA 陽性細胞 の比率 $64.6 \%$ に比して，相対的に低下していた。

Table 3 Interstitial deposition of $\mathrm{Ig}$ and $\mathrm{C}_{1} \mathrm{q}$ in eight normal lungs

Sites of immure diposits

1. alveolar septum

2 . intravascular space 4, alveolar macrophage

\begin{tabular}{|c|c|c|c|c|c|c|c|c|c|c|c|c|c|c|c|c|c|c|c|c|c|c|c|c|c|}
\hline \multirow{2}{*}{$\begin{array}{c}\text { Case } \\
\text { no }\end{array}$} & \multicolumn{5}{|c|}{$\mathrm{IgG}$} & \multicolumn{5}{|c|}{$\operatorname{IgA}$} & \multicolumn{5}{|c|}{ IgM } & \multicolumn{5}{|c|}{$\lg E$} & \multicolumn{5}{|c|}{$C_{1} q$} \\
\hline & 1 & 2 & 3 & 4 & 5 & 1 & 2 & 3 & 4 & 5 & 1 & 2 & 3 & 4 & 5 & 1 & 2 & 3 & 4 & 5 & 1 & 2 & 3 & 4 & 5 \\
\hline 1 & \pm & - & - & \pm & - & \pm & \pm & - & \pm & - & - & - & - & - & - & - & - & - & - & - & \pm & - & - & \pm & - \\
\hline 2 & - & - & - & \pm & - & - & - & - & - & - & - & - & - & - & - & - & - & - & - & - & \pm & - & - & \pm & - \\
\hline 3 & - & - & - & - & - & - & - & - & - & - & - & - & - & - & - & - & - & - & - & - & \pm & - & - & \pm & - \\
\hline 4 & - & - & - & \pm & - & - & - & - & \pm & - & - & - & - & - & - & - & - & - & - & - & - & - & - & \pm & - \\
\hline 5 & - & - & - & - & - & - & - & - & \pm & - & - & - & - & - & - & - & - & - & \pm & - & - & - & - & \pm & - \\
\hline 6 & - & + & - & - & - & - & + & - & - & - & - & + & - & - & - & - & - & - & - & - & - & - & - & \pm & - \\
\hline 7 & - & - & - & - & - & - & - & - & - & - & - & - & $-\cdots$ & - & - & - & - & - & - & - & - & - & - & - & - \\
\hline 8 & - & - & - & - & - & - & - & - & - & - & - & - & - & - & - & - & - & - & - & - & - & - & - & - & - \\
\hline
\end{tabular}

Table 4 Immunohistological findings of thirteen diseased lungs

\begin{tabular}{|c|c|c|c|c|c|c|c|c|c|c|c|}
\hline \multirow{2}{*}{$\begin{array}{c}\text { Case } \\
\text { no }\end{array}$} & \multirow{2}{*}{ Diagnosis } & \multicolumn{5}{|c|}{ Ig cell counts $/ 10 \mathrm{~mm}^{2},() \%$} & \multicolumn{5}{|c|}{ Interstitial deposits } \\
\hline & & $\lg G$ & $\operatorname{IgA}$ & $\operatorname{IgM}$ & & $\lg E$ & $\operatorname{Ig} G$ & $\operatorname{Ig} A$ & $\lg M$ & IgE & $\mathrm{C}_{1} \mathrm{q}$ \\
\hline 9 & IIP & $387(43.8)$ & $380(43.2)$ & $100(11.4)$ & 13. & $(11.5)$ & $2+$ & + & + & - & + \\
\hline 10 & IIP & $403(43.6)$ & $455(49.0)$ & $51(5.5)$ & 19 & $(2.0)$ & + & + & + & - & + \\
\hline 11 & $\operatorname{IP}(\mathrm{RA})$ & Uncountable & 110 & 79 & & 0 & $2+$ & + & + & - & + \\
\hline 12 & IP (RA) & Uncountable & 1885 & 833 & & 77 & $2+$ & + & + & - & - \\
\hline 13 & $\mathrm{HP}$ & $488(28.1)$ & $1000(57.6)$ & $250(14.4)$ & 0 & $(0)$ & + & - & - & - & + \\
\hline 14 & HP & $473(15.9)$ & $1845(62.1)$ & $655(22.0)$ & 0 & $(0)$ & $2+$ & + & + & - & - \\
\hline 15 & $\mathrm{HP}$ & $405(27.1)$ & $957(64.1)$ & $133(8.8\rangle$ & 0 & $(0)$ & + & \pm & \pm & - & - \\
\hline 16 & Sarcoidosis & $242(28.6)$ & $375(44.1)$ & $232(27.3)$ & 0 & $(0)$ & + & - & \pm & - & $2+$ \\
\hline 17 & Sarcoidosis & $174(42.5)$ & $151(37.0)$ & $48(11.8)$ & 19 & $(4.7)$ & + & \pm & - & - & $2+$ \\
\hline 18 & Sarcoidosis & Uncountable & 162 & 76 & & 0 & $2+$ & + & + & - & $2+$ \\
\hline 19 & DPB & $113(40.4)$ & $92(33.0)$ & $71(25.2)$ & 4 & $(1.1)$ & + & + & - & - & - \\
\hline 20 & $\mathrm{DPB}$ & Uncountable & 753 & 807 & & 53 & $2+$ & + & + & - & - \\
\hline 21 & $\mathrm{DPB}$ & $379(34.6)$ & $543(49.7)$ & $171(15.7)$ & 0 & $(0)$ & + & + & + & - & \pm \\
\hline
\end{tabular}




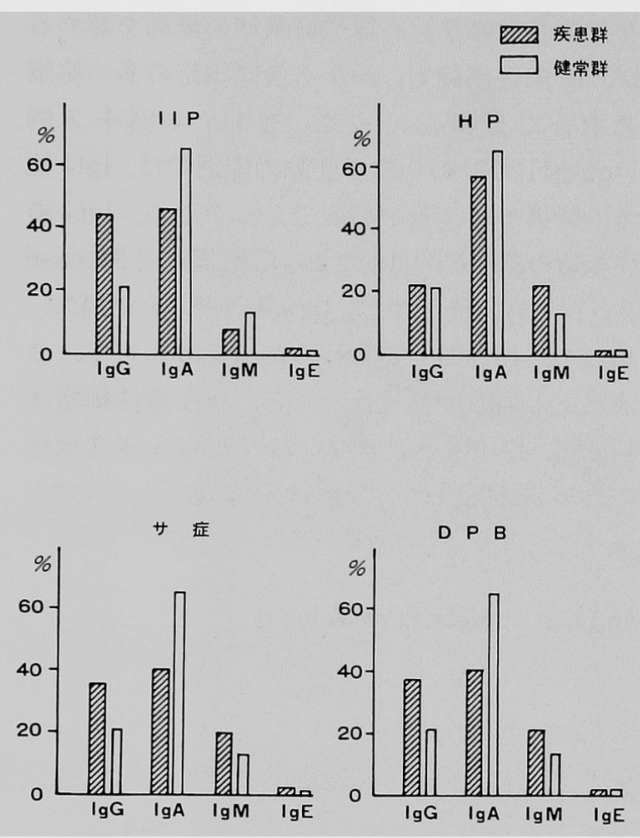

Fig. 3 Ratio of each Ig containing cell counts in interstitial lung diseases
$\operatorname{IgM}$ 陽性細胞は, case12のリウマチ肺の症例で 多数認められた。一方, 間質への沈着は, 肥厚 した胞隔を中心に, IgG 抗体の高度の沈着が認 められた。特にリウマチ肺にその傾向が著明で あった (Photo 2)。IgA と IgM については, $\operatorname{IgG}$ ほど著明ではないが 4 例全例に沈着を認め た。 $\mathrm{C}_{1} \mathrm{q}$ は 4 例中 3 例に沈着を認めた。

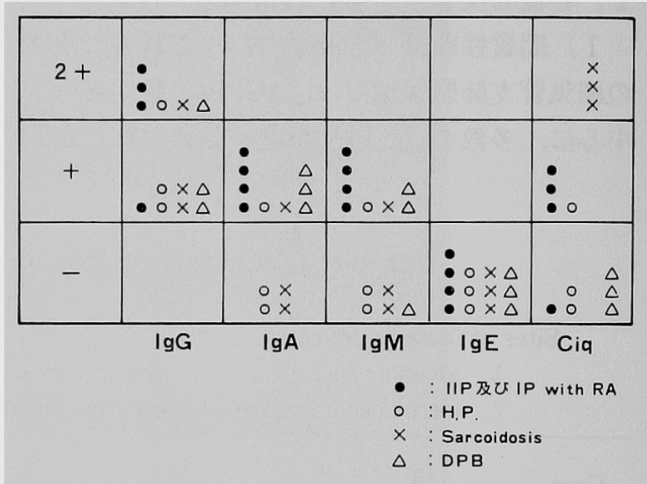

Fig. 4 Ig and $\mathrm{C}_{1} \mathrm{q}$ deposition to alveolar septa in interstitial lung diseases

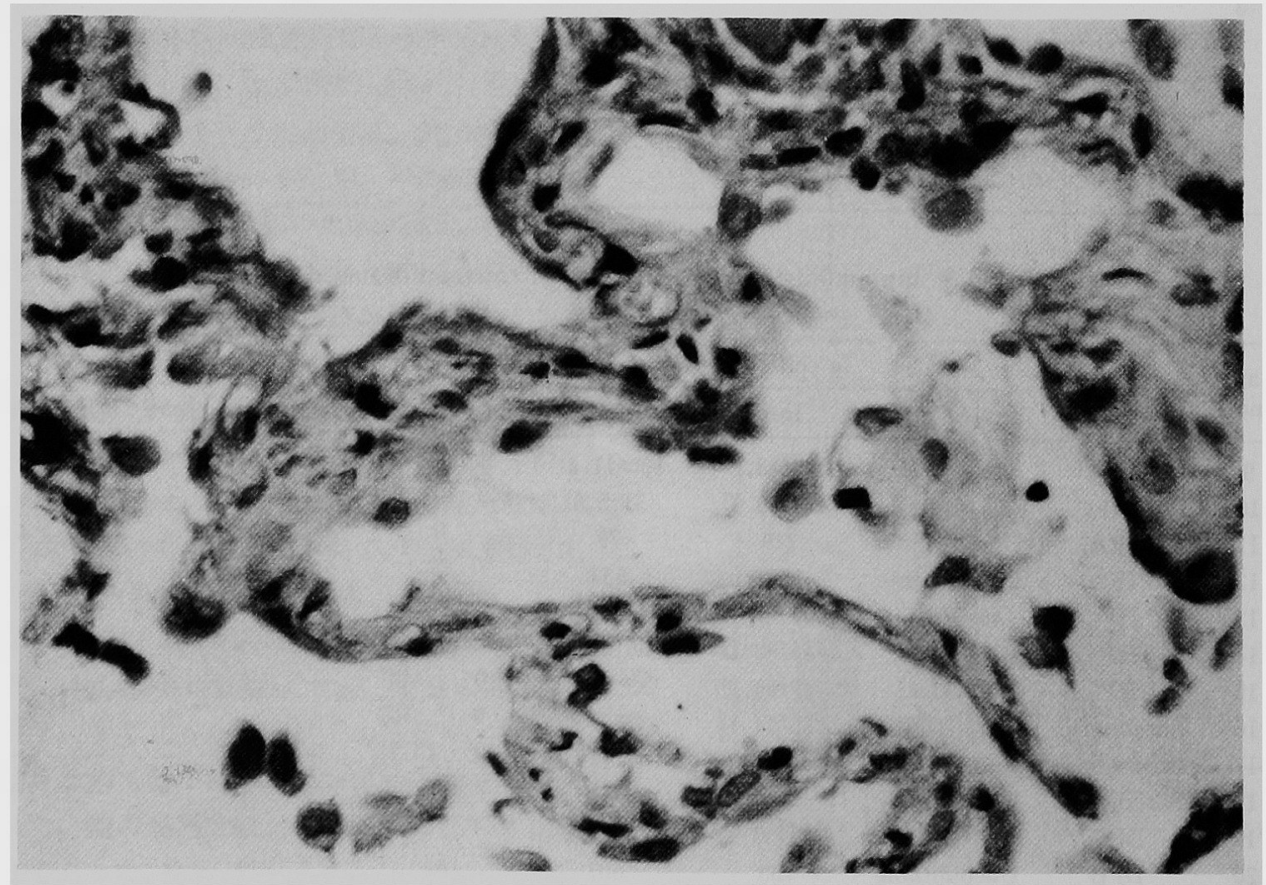

Photo 2 IgG deposition to the septa of rheumatic lung $(\times 400)$ 
2 ) 過敏性肺䑏炎 (case13-15)：本症は病理 学上 alveolitis や granuloma を認め, 胞隔は 著明に肥厚するが, IIP 程線維化は著明ではなく， 単核球の浸潤が主体である。Ig 陽性細胞も，そ の浸潤単核球の中に多数認められた。間質への 沈着は, IgG 抗体が全例に陽性を示したが, IP 程高度ではなかった。

3) サルコイドーシス(casel6-18) : IgG, IgA, IgM 陽性細胞の全般的な増加を認めた。 Ig 陽性 細胞は, 肥厚した胞隔と, サルコイド結節の周 辺部に多く存在していた。また, 間質への沈着 は, IgG 抗体及び $\mathrm{C}_{1} \mathrm{q}$ が 3 例全例に陽性であり, 特に, $\mathrm{C}_{1} \mathrm{q}$ のサルコイド結節辺縁部への沈着が 特徴的であった（Photo 3 )。

4) びまん性汎細気管支炎 (case19-21)：Ig 陽性細胞は, 細胞浸潤の多い細気管支粘膜領域 に集中して認められた。IgG, IgA, IgM 陽性細 胞が, いずれも多数認められたが, 健常肺に比 して, IgG と IgM 陽性細胞の増加傾向が認め られた。また，細気管支粘膜を中心とする間質 に, IgG, IgA, IgM 抗体の沈着が認められた
(Photo 4 )。

考案

肺の免疫組織学的研究は, 蛍光抗体法や酵素 抗体法などの免疫組織化学の発展にともない, 主に剖検肺を用いて行われた。例之ば MartinetzTello ら ${ }^{11}$ は1968年に, 肺線維症患者の剖検肺の 気管支粘膜下に, IgA 及びIgG 陽性細胞を証明 し，また健常肺に於ける系統的研究は，1969年

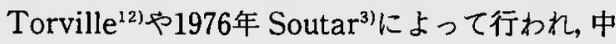
枢気道粘膜においては IgA 陽性細胞が優位であ ることが，報告されている。今回著者は，健常 人及び免疫アレルギー疾患での末梢気道（細気 管支, 肺胞レべル）の免疫学的特徵を解明する ために，酵素抗体法による免疫染色を行った結 果，健常肺に於いては，Ig陽性細胞は主に basement membrane 下の lamina propria に分布 しており，特に small bronchiole 周辺に多く， 胞隔にも散見されるが極少数であった。Igクラ ス別に見ると, IgA 陽性細胞が平均 $64.6 \%$ と過 半数を占め, 中枢側気道と同様末梢気道におい

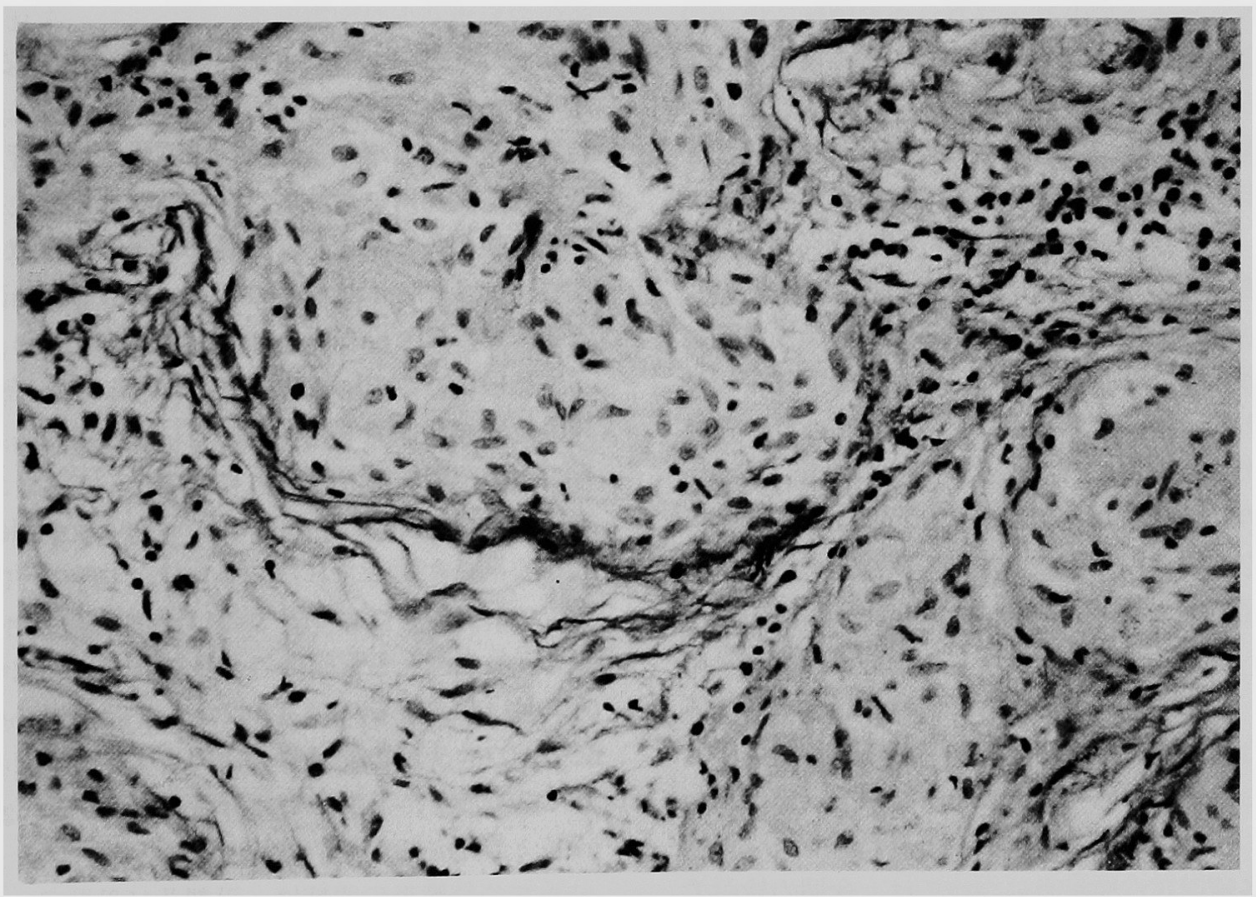

Photo $3 \mathrm{C}_{1} \mathrm{q}$ deposition around granulomas of sarcoidosis $(\times 400)$ 


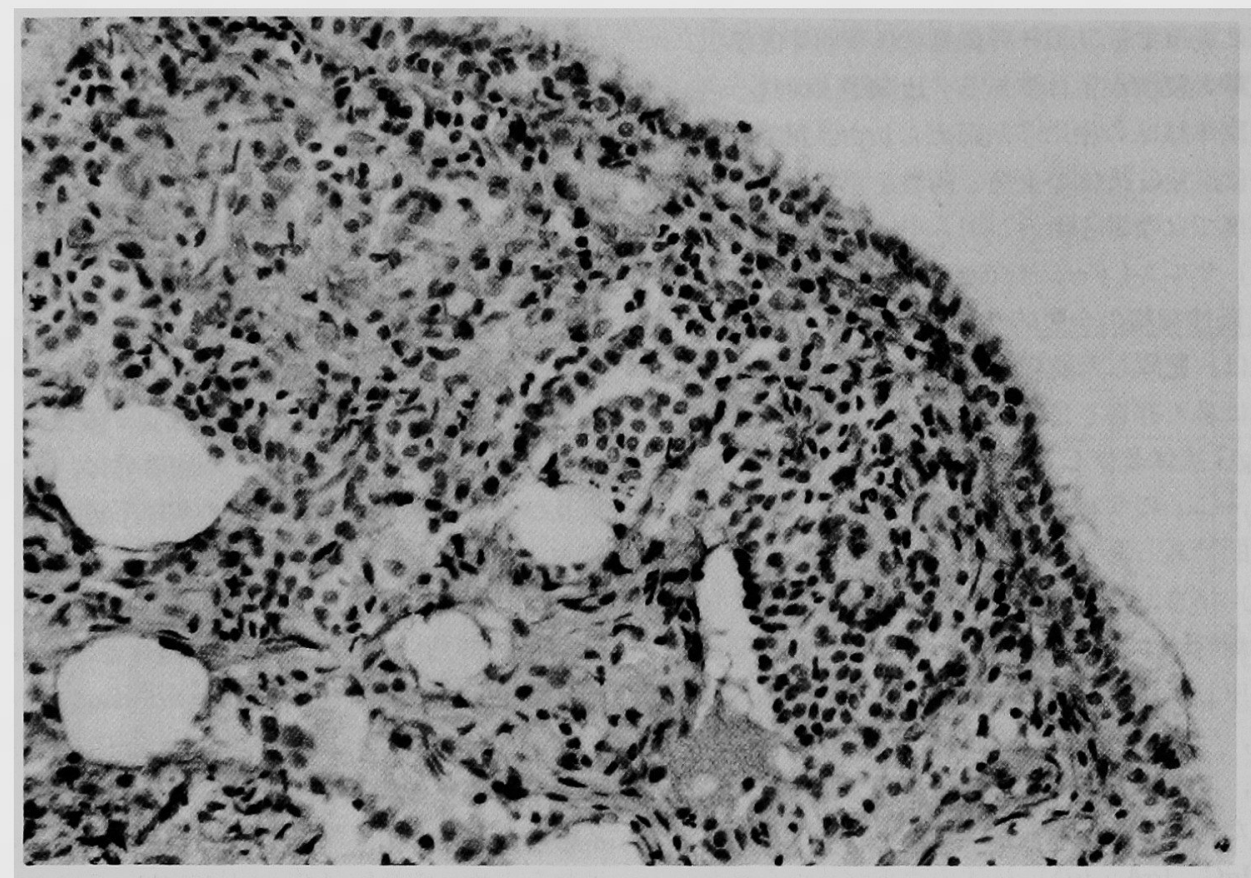

Photo 4 IgG containing cells abundantly seen in the bronchiolar mucosa of diffuse panbronchiolitis $(\times 200)$

ても，IgA が液性免疫防御機構の主役を演じて いるものと考えられた。一方，IgG 陽性細胞は 平均 $20.1 \%$, IgM 陽性細胞は平均 $13.7 \%$, や や低率であり再者間に有意差は認められなかっ た。しかし， IgE 陽性細胞は平均 $1.6 \%$ と他のIg 陽性細胞に比し著明に低率であった（ $\mathrm{p}<0.01 ） 。$ 従って健常人の末梢肺領域における Ig陽性細胞 の分布は， $\operatorname{IgA}$ が優位で，ついで IgG 及びIgM であり，IgEは最も少数であった。

次に, 肺間質へのIg 及び $C_{1} q$ の沈着は, case 6 の脈管腔内に残存血液成分と思われる IgM 抗 体を認めた以外は，いずれの症例にも陽性所見 は認められなかった。Alveolar macrophage 内 に，しばしば IgG, IgA， C 1 q が弱陽性を示した が,これは macrophageに鋇食された抗原抗体 複合物の残存と推定された。酵素抗体法は明ら かな陽性像に限って意義を持つ検査法であるか ら，弱陽性の意義は少ないと思われる。

各種間質性肺疾患については，今回の検討で は症例数が少ないため総括的な解析は困難であ
るが, いつかの興味ある所見が得られている。 すなわち，各疾患とも IgG，IgA，IgM 陽性細 胞数が，著明に堌加しており，胞隔や細気管支 の炎症病変局所における活発な細胞反応と免疫 活動が窺われた。また，胞隔や細気管支領域の 間質には, IgG をはじめ種々の immune deposits を認めた。IIP (case 9，10)では， alveolitisを 示す胞隔に多数のIg陽性細胞の浸潤を認め,特に IgG 陽性細胞が著明に増加していた。また，胞 隔に IgG, IgA, IgM, $C_{1} q$ の沈着を認めた。か かる所見から, IIP の病態に immune complex の梁い関与が示唆された。さらにリウマチ肺 (case11，12）では IIP とほぼ同様の所見を得 たが, 2 症例とも胞隔への IgGの沈着が特に強 く，IgG 陽性細胞の識別ができないはどであっ た。リウマチ肺の組織障害に関しては，IgM 優

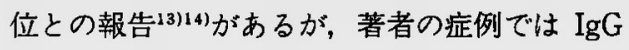
優位と思われた。

過敏性肺臟炎の病態は, III型及びIV 型アレル ギー反応の関与 ${ }^{6)}$ が想定されている。すなわち， 
病理組織像からは単核球浸潤を伴う granulomatous alveolitis であり，N型アレル ギーの関与が示唆され，また，今回検討した 3 症例の免疫染色からは IgGの胞隔への沈着や 1 例 (case13) の胞隔には IgGと $\mathrm{C}_{1} \mathrm{q}$ の沈着も 認められ, immune complexの存在が窥われ, III型アレルギーの関与が証明された。

サルコイドーシスでは, 間質における immune deposits が注目された。IgGと $\mathrm{C}_{1} \mathrm{q}$ が 3 例全例 に沈着しており，特に granuloma の周辺部に 強く認められた。また, 同部にはIg陽性細胞も多 数分布しており，同部における活発な免疫活動 が窥られた。

びまん性沉細気管支炎では，細胞反応の活発 な細気管支領域を中心に, Ig陽性細胞の增加か認 められた。case19の細気管支領域には，BALT 様のリンハ球の集族が認められたが，同部には Ig陽性細胞は認められなかった。間質への沈着は， Ig陽性細胞の多数浸潤している細気管支粘膜を 中心に, IgG, IgA を認めたが, $\mathrm{C}_{1} \mathrm{q}$ は除性だっ た。

間質に置けるIgの存在には 2 つの機㢁が考之 られる。ひとつは，炎症反応により血液中の蛋 白成分が炎症組織内に浸出してくるか, 局所に 浸潤した形質細胞より Ig が分泌される場合であ $\eta$, 感染などの非特異的炎症が原因上考之られ る。他方は，アレルギーなどの特異的免疫反応 が関与している場合であり，前者との識別は容 易ではないが, Ig と同時に補体が存在している 場合は, immune complex による組織障害が惹 起されている可能性が考えられる。特に $\mathrm{C}_{1} \mathrm{q}$ は， classical passway を介してのみ活性化される補 体であり， $\mathrm{C}_{1} \mathrm{q}$ の存在は抗原特異的免疫反応を 示唆すると考之られる。今回の著者の検討では， IIP とサ症で, 高率に $\mathrm{C}_{1} \mathrm{q}$ の沈着を認めたが, DPBでは認められず, 異なった免疫反応の関与 が示唆された。なお，本編で検棓した呼吸器疾 患では, IgG, IgA, IgM 陽性細胞の絶対的增加 が認められたが，IgE 陽性細胞はいずれも極低 率であり，かかる呼吸器疾患の病態にI型アレ ルギー反応の関与はないものと思かれた。

\section{結語}

肺末梢気道領域の免疫学的特徵を明らかにす る研究の一助として，健常肺および各種間質性 肺疾患 (IP, HP, サ症, DPB)の末梢肺組織に 酵素抗体法による免疫染色を試み，以下の知見 を得た。

1.パラフイン切片を用いたPAP法は，組織 構造の保持並びに免浚グロブリンの抗原性の保 持に優れ、染色態度も明瞭で，末梢肺のような 微細な組織の観察に適していた。

2. 健常肺の末梢気道領域では, 細気管支粘 膜を中心に, IgA 産生細胞が64.6\%と優位を占 めていた IgGや IgM 産生細胞もそれぞれ20.1 \%, 13.7\%認められたが, IgE 産生細胞は殆ど 認められなかった。間質には兔疫グロブリンや 補体の沈着は認められなかった。

3.間質性肺疾患の末梢肺では, 全般的に健 常肺に比して IgG，IgA， IgM 産生細胞の著明 な增加が認められ，間質には種々の immune deposits が認められた。特に間質性肺炎では, IgG 産生細胞が著增しており，胞隔には IgGや $\mathrm{C}_{1} \mathrm{q}$ の沈着が認められた。サルコイドーシスで は, 肉芽腫の周辺に $\operatorname{IgG} と \mathrm{C}_{1} \mathrm{q}$ の沈着が認め られ，immune complex の関与が筅われた。ひ まん性汎細気管支炎では, 細気管支領域に, IgG, IgA，IgM の沈着が認められたが， $\mathrm{C}_{1} \mathrm{q}$ は認め られなかった。

以上，健常肺での免疫グロブリンの防御機構 並びに，免疫の関与が想定される間質性肺疾患 の，肺末梢領域における免疫グロブリン及び免 疫複合体の関与が明らかになった。

稿を終わるにあたり，御指導、御校閲を賜わりま した恩師木村郁郎教授に深謝致します。さらに，直 接御指導, 御教示いただいた高橋清講師に深謝致し ます。

なお，本論文の要旨は，第35回日本アレルギー学 会総会 (昭和60年 7 月28日) において発表した。 
1) Falk GA, Okinaka IJ, and Siskind GW : Immunoglobulins in the bronchial washings of patients with chronic obstructive pulmonary disease. Am Rev Respir Dis (1972) 105, 14.

2) Brandtzaeg P : Mucosal and grandular distribution of immunoglobulin components. J Immunol (1974) 112, 1153-1159.

3) Soutar CA : Distribution of plasma cells and other cells containing immunoglobulin in the respiratory tract of normal man and class of immunoglobulin contained therein. Thorax (1976) 31, 158.

4) Callerame ML : Immunogrobulins in bronchial tissues from patients with asthma, with special reference to IgE. J Allergy (1971) 47, 187.

5) Nagay $H$, Elmore $M$, Ford $C D$ : Idiopathic interstitial pulmonary fibrosis. An immune complex disease? Am Rev Respir Dis (1973) 107, 826.

6) Schatz M : Immunopathogenesis of hypersensitivity pneumonitis. J Allergy Clin Immunol (1977) 60. 27.

7) Parish WE : Short-term anaphylactic IgG antibodies in human sera. Lancet (1970) 2, 591-592.

$8 ）$ 本村郁郎：瑞息の病型とその本質論一中高年発症型難治性喘息の独立性. 日胸疾患会誌（1983）21, 181一 182.

9 ）谷崎勝朗：気管支喘息における肺の細胞反忘を中心とした組織学的変化について.アレルギー (1983) 32, 229-236.

10）木村郁郎, 高檽清：末梢気道に変化を伴った中高年発症重症難治性喘息症例の検討.アレルギーの臨 (1984) 35, 210-212.

11) Martinetz-Tello FJ : Immunogrobulin production in bronchial mucosa and bronchial lymphnode, particularly in cystic fibrosis of the pancreas. J Immunol (1968) 101, 989.

12) Torville DR, Adler RH : The human secretory immunoglobulin system. J Exp Med (1969) 129, 411.

13) De Haratius RJ : Immunofluorescent and immunologic studies of rheumatic lung. Arch Intern Med (1972) $129,441$.

14）遠藤富士夫：特発性間質性肺炎及び膠原病に伴う間質性肺炎の免疫組織学的ならじに臨床的検討. 日胸疾患 会誌 (1983) 21，1049. 


\section{Studies on immune response in small airways in patients with allergic respiratory diseases \\ Part 1. Immunohistological studies of peripheral airways \\ in interstitial lung diseases \\ Kimitaka OzAKI

\author{
Okayama University Medical School, \\ Okayama 700, Japan
} \\ Second Department of Internal Medicine, \\ (Director : Prof. I. Kimura)}

To clarify the immunological characteristics of small airway areas, an unlabelled antibody peroxidase method for the detection of $\operatorname{IgG}, \operatorname{IgA}, \operatorname{IgM}, \operatorname{IgE} \&$ complement $\left(\mathrm{C}_{1} q\right)$ was applied to human peripheral lung tissues from patients with or without immunological respiratory diseases. Normal lung tissues were obtained from 8 surgically resected lungs with primary carcinoma.

In normal peripheral lungs, immunoglobulin containing cells were mainly distributed around the bronchiolar mucosa, but were sometimes found in alveolar septa. IgA containing cells were most numerous (mean 64.6\%), followed by IgG containing cells (mean $20.1 \%$ ) and IgM containing cells (mean $13.7 \%$ ). IgE containing cells were virtually absent from small airway areas. No interstitial deposition of immuoglobulins or complement was detected in normal peripheral lung tissues.

In peripheral lungs with interstitial lung diseases, immunoglobulin containing cells were generally increased in number compared with normal lungs. Among them, IgG containing cells were dominant especially in interstitial pneumonia cases. In peripheral interstitium, various immune depositions were observed. Marked $\operatorname{IgG}$ and $C_{1} q$ deposits were seen in thickened septa of interstitial pneumonia and around granulomas of sarcoidosis, suggesting a relation between immune complex and these diseases. In diffuse panbronchiolitis, there were many IgG containing cells around the bronchiolar area.

These findings indicate that the IgA antibody was dominant in the immunological defence mechanism of the normal peripheral lung, whereas IgG antibody and complement as well as IgA antibody were important in immuological respiratory diseases. 